\title{
Effect of feeding level and linseed oil on some metabolic and hormonal parameters and on fatty acid profile of meat and fat in growing pigs
}

\author{
JUSTYNA WIĘCEK', ANNA REKIEL' ${ }^{1}$ and JACEK SKOMIAŁ ${ }^{2}$ \\ 'Department of Pig Breeding, Faculty of Animal Sciences, Warsaw University of Life Sciences, Poland, ${ }^{2}$ The \\ Kielanowski Institute of Animal Physiology and Nutrition, Polish Academy of Sciences, Jablonna, Poland
}

\section{Abstract}

In an experiment with 56 pigs, the effects of feeding level and linseed oil supplement on fattening and slaughter parameters, the weight of internal organs, the concentration of hormones and indicators of protein and lipid metabolism, and the fatty acid profile of $m$. semimembranosus and backfat were investigated. During the growing period, all animals received a feed supplemented with $4 \%$ linseed oil. At the end of the growing period (23-61 kg body weight), compared to semi-ad libitum fed animals, animals that were fed restrictively ( $25 \%$ less feed) during this period were characterized by lower daily gains $(P \leq 0.001)$, greater meatiness $(P \leq 0.01)$, lower weight of internal organs, higher level of growth hormone $(P \leq 0.05)$, lower levels of thyroid-stimulating hormone and blood urea nitrogen $(P \leq 0.05)$, and dietetically more beneficial profile of fatty acids (more polyunsaturated fatty acids [PUFA]). During realimentation (61-104 kg body weight), when all animals were fed semi-ad libitum diets with 0 or $4 \%$ linseed oil, daily feed intake and daily weight gains of the pigs that had previously been restrictively fed, were greater than in animals fed semi-ad libitum throughout fattening. Compensatory growth was found for the internal organs. Animals that received linseed oil diets throughout fattening were characterized during the finishing period by a higher rate of growth $(P \leq 0.001)$, higher concentrations of triiodothyronine $\left(T_{3}\right)$ and insulin $(P \leq 0.05)$, and a greater proportion of $\mathrm{n}-3$ PUFA in the fatty acid profile of $m$. semimembranosus and backfat $(P \leq 0.001)$.

Keywords: pigs, level of feeding, linseed oil, biochemical indicators of blood, fatty acid profile

\section{Zusammenfassung}

\section{Einfluss von Fütterungsniveau und Leinölzusatz auf einige Stoffwechsel-, Hormonparameter und Fettsäureprofile im Fleisch und Fett von Mastschweinen}

An 56 Mastschweinen (28 Börge und 28 weibliche Tiere) wurde in zwei Gruppen der Einfluss des Ernährungsniveaus sowie eines Leinöl-Futterzusatzes auf die Mast- und Schlachtleistungen, Hormone, Blutindikatoren sowie das Fettsäureprofil im M. semimenbranosus und im Rückenspeck untersucht. Die Fütterung der Gruppe A erfolgte semi ad libitum und die der Gruppe R restriktiv ( $25 \%$ weniger Futter). Im Mastabschnitt von 23 bis $61 \mathrm{~kg}$ erhielten alle Tiere einen Futterzusatz von 4\% Leinöl. Die zweite Mastperiode erstreckte sich von 61 
bis 104 kg. Die A-Tiere erzielten signifikant geringere Zunahmen, höhere Fleischanteile und geringere Gewichte innerer Organe. Das Niveau des Wachstumshormons war höher, während sich das des Thyroidhormon sowie der Blutharnstickstoffgehalt als geringer erwiesen. Durch den höheren Anteil an mehrfach ungesättigten Fettsäuren (PUFA) erzielten diese Tiere ein besseres Fettsäureprofil. In der Untergruppe RO, die 4\% Leinöl erhielt, waren Futteraufnahme und Mastleistung der Tiere, welche vorher restriktiv gefüttert wurden, höher als bei der semi ad libitum Gruppe. Bei den Tieren mit Futterrestriktion konnte ein kompensatorisches Wachstum der inneren Organe beobachtet werden. Die Tiere, welche während der gesamten Versuchsdauer einen Leinölzusatz erhielten, erreichten im zweiten Mastabschnitt signifikant höhere Tageszunahmen, höhere Triiodthyronin $\left(\mathrm{T}_{3}\right)$ - und Insulinwerte sowie einen höheren PUFA n-3 Anteil sowohl im M. semimembronosus als auch im Rückenspeck.

Schlüsselwörter: Schwein, Ernährungsniveau, Leinsamenöl, biochemische Blutindikatoren, Fettsäureprofil

\section{Introduction}

Feeding level and diet composition affect the animal's growth rate, the body's hormonal metabolism and the quantity and quality of fat deposited during growth. During the period of limited feed supply, a considerable decrease in the weight of internal organs (WIĘCEK et al. 2006), a low serum concentration of thyroid hormones (SAGGAU et al. 2000, SAWOSZ et al. 2005), and a high serum concentration of the growth hormone (HORNICK et al. 2000) were found. It was shown that restricted feeding may affect the relationships between the intake of fatty acids and their level in individual tissues (WIĘCEK and SKOMIAŁ 2004, DAZA et al. 2006, WIĘCEK et al. 2008). However, the fatty acid profile of animal tissues is influenced to a greater extent by the type of feed than the quantity of feed consumed (LEIBETSEDER 1996, WIĘCEK and SKOMIAŁ 2004, PEINADO et al. 2009). The addition of oils to the diets increases the percentage proportion of polyunsaturated fatty acids (PUFA) in animal tissues (MASON et al. 2005, VÁCLAVKOVA and BEČKOVÁ 2007).

Compensatory growth has been found in livestock species such as cattle and pigs, exposed to limited feed supply or lower feed quality (HORNICK et al. 2000). The response of animals varies according to the body weight at which feed restriction was started, the duration of restricted feeding and realimentation, and the extent to which feeding is restricted (SKIBA 2005, BEE et al. 2006a, 2006b, DAZA et al. 2006, HEYER and LEBRET 2007).

The aim of the study was to determine the effect of feeding level and linseed oil supplement on the productivity, metabolic and hormonal parameters, and fatty acid profile of $m$. semimembranosus and backfat in pigs.

\section{Material and methods}

The experiment was carried out with 56 Polish Large White $\times$ Polish Landrace $\times$ Duroc fattening pigs ( 28 barrows and 28 gilts). The study began when pigs weighed approximately $23 \mathrm{~kg}$. Eight pigs (group 0) were slaughtered at the beginning of the experiment and the other 48 pigs were assigned based on the analogue principle to two groups: A and R. 
Animals were fed individually with growing (23-61 kg body weight) and finishing diets (61-104 kg body weight) (Table 1). During the growing period, animals from group A were fed semi-ad libitum, and those from group $\mathrm{R}$ were fed restrictively (approximately $75 \%$ of semi-ad libitum) (Table 2). In the finishing period, all animals were fed semi-ad libitum, and each group (A and R) was divided into 2 subgroups. Feeds supplemented with $4 \%$ linseed oil were given to all animals during the growing period and to animals from groups $A O$ and $\mathrm{RO}$ during the finishing period. The feeds of pigs from groups $A C$ and $\mathrm{RC}$ contained no linseed oil.

Table 1

Composition (\%) and nutritive value of the mixtures

Zusammensetzung (\%) und Nährwert der Mischungen

\begin{tabular}{lccc}
\hline \multirow{2}{*}{$\begin{array}{l}\text { Specification } \\
\text { Growing period 23-61 kg }\end{array}$} & \multicolumn{2}{c}{$\begin{array}{c}\text { Mixtures for: } \\
\text { Finishing }\end{array}$} \\
& & Group AC and RC & 61-104 kg \\
Wheat meal & 18.00 & 35.68 & 37.00 \\
Barley meal & 54.86 & 42.00 & 42.00 \\
Wheat bran & - & 11.00 & - \\
Soybean meal & 20.00 & 8.60 & 14.00 \\
Linseed oil & 4.00 & - & 4.00 \\
Vitamin E & 0.30 & - & 0.30 \\
Mineral-vitamin mix & 2.00 & 2.00 & 2.00 \\
L-lysine & 0.30 & 0.30 & 0.26 \\
DL-methionine & 0.42 & 0.32 & 0.34 \\
L-threonine & 0.12 & 0.10 & 0.10 \\
Nutritive value of the diets (analyzed) & & \\
EM, MJ/kg & 13.5 & 12.5 & 13.5 \\
Crude protein, $\%$ & 16.5 & 13.5 & 14.5 \\
Ether extract, $\%$ & 4.48 & 1.71 & 3.63 \\
Crude fibre, $\%$ & 3.80 & 4.09 & 3.44 \\
Ash, $\%$ & 4.19 & 3.57 & 4.76 \\
Lys, $\%$ & 1.06 & 0.82 & 0.88 \\
Composition of fatty acids (\% total acids) & 19.0 & & \\
SFA & 26.4 & 24.3 & 28.2 \\
MUFA & 29.1 & 20.3 & 34.4 \\
PUFA n-6 & 25.5 & 47.6 & 23.1 \\
PUFA n-3 & 1.1 & 7.8 & 14.3 \\
PUFA n-6/n-3 & 6.1 & 1.6 \\
\hline
\end{tabular}

EM metabolizable energy, SFA saturated fatty acid, MUFA monounsaturated fatty acid, PUFA polyunsaturated fatty acid

Table 2

The experimental design

Versuchsaufbau

\begin{tabular}{|c|c|c|c|c|c|}
\hline \multirow{2}{*}{ Fattening period } & \multirow{2}{*}{ Item } & \multicolumn{4}{|c|}{ Group } \\
\hline & & $A C$ & $\mathrm{AO}$ & $\mathrm{RC}$ & RO \\
\hline Growing & Level of feeding & \multicolumn{2}{|c|}{ semi ad libitum } & \multicolumn{2}{|c|}{ Restrictive ( $25 \%$ less feed } \\
\hline $23-61 \mathrm{~kg}$ & $\%$ linseed oil & 4 & 4 & 4 & 4 \\
\hline Finishing & Level of feeding & \multicolumn{4}{|c|}{ semi ad libitum } \\
\hline $61-104 \mathrm{~kg}$ & $\%$ linseed oil & 0 & 4 & 0 & 4 \\
\hline
\end{tabular}


Body weight and feed intake were recorded during fattening. During the experiment, blood was taken from 32 pigs three times: at the beginning of the growing period ( $v$. cava cranialis); at the end of the growing period (v. auricularis lateralis); and at the end of the finishing period (a. carotus communis). Blood collected $4 \mathrm{~h}$ after the morning feeding was centrifuged (10 $\mathrm{min} 3500 \mathrm{r} / \mathrm{min}$ ) and the level of serum hormones was determined by radioimmunoassay. Analytical tests included the determination of growth hormone (GH), thyroid-stimulating hormone (TSH), triiodothyronine $\left(\mathrm{T}_{3}\right)$, thyroxine $\left(\mathrm{T}_{4}\right)$ and insulin. The determinations were made on a Cobra II gamma counter (Canberra Packard), using iodine-125-labelled hormones.

At the end of the growing period ( $61 \mathrm{~kg}$ body weight), 16 animals (gilts : barrows, 1:1) were randomly chosen ( 8 from group A and 8 from group R) and slaughtered. All the other animals were slaughtered ( $104 \mathrm{~kg}$ body weight) at the end of the finishing period ( 8 animals each from groups $\mathrm{AC}, \mathrm{AO}, \mathrm{RC}$ and $\mathrm{RO}$ ).

The blood serum collected at slaughter $(n=56)$ was analysed for biochemical indicators by dry chemistry assay using a Vitros DT 60 II System and diagnostic kits from ICN Instruments Polska Sp. z 0.o. The determinations included total protein (TP), albumin (ALB), glucose (GLU), blood urea nitrogen (BUN), triacylglycerols (TG), total cholesterol $(\mathrm{CH})$ and high-density (HDL), low-density (LDL) and very low-density lipoproteins (VLDL).

After slaughter, the weight of internal organs (spleen, stomach, liver, pancreas, kidneys and heart) was determined in all the animals. 24-h chilling of half-carcasses was followed by a measurement of backfat thickness behind the last rib and determination of meatiness based on complete dissection in accordance with the Polish Pig Testing Station procedures (RÓŻYCKI 1996). A slice of backfat from the 13th-/14th-rib interface and a slice of $m$. semimembranosus were collected. The preparation and analysis of methyl esters of fatty acids were performed by gas chromatography (PN 5508, PN 5509) using a Hewlett Packard 6890 Series GC System with an FID detector, a BPX 70 capillary column and helium as a carrier gas. Individual peaks were expressed as percentage of total fatty acids.

The results were analysed statistically by means of one- or two-way analysis of variance using the least squares method. The statistical model accounted for the effect of feeding level during the growing period and the effects of feeding level during the growing period and linseed oil supplement during the finishing period (SPSS 2006). Values of traits of animals slaughtered at approximately $23 \mathrm{~kg}$ of body weight are shown as arithmetic means.

\section{Results}

During the growing period, the daily gains of intensively fed animals (group A) were approximately $30 \%$ higher than those of restrictively fed animals (group R) and the duration of fattening from 23 to $61 \mathrm{~kg}$ body weight was 19 days shorter $(P \leq 0.001)$ (Table 3 ). During the finishing period, the highest growth rate and the best feed conversion ( $\mathrm{kg} \mathrm{feed} / \mathrm{kg}$ gain) were found in animals from group AO (Table 4). The linseed oil supplemented to feed had a significant effect on the duration of fattening $(P \leq 0.05)$, daily gains $(P \leq 0.001)$, total feed intake $(P \leq 0.05)$ and feed conversion $(P \leq 0.001)$. Regardless of feed type, animals that were feed restricted during the growing period had a higher daily intake of feed $(P \leq 0.001)$ compared to pigs from groups $A C$ and $A O$. 
Table 3

Production results in growing period

Mast- und Schlachtergebnisse im 1. Mastabschnitt

\begin{tabular}{|c|c|c|c|c|c|}
\hline \multirow{2}{*}{ Item } & \multirow{2}{*}{ Group 0} & \multicolumn{2}{|c|}{ Group } & \multirow{2}{*}{ SEM } & \multirow{2}{*}{$P$} \\
\hline & & A & $\mathrm{R}$ & & \\
\hline Initial body weight, kg & & 23.1 & 23.3 & 0.32 & ns \\
\hline Final body weight, kg & & 61.2 & 61.1 & 0.49 & ns \\
\hline Days of fattening & & 48 & 67 & 0.88 & $* * *$ \\
\hline Daily weight gain, $\mathrm{g}$ & & 806 & 568 & 12.75 & $* * *$ \\
\hline Daily feed consumption, $\mathrm{kg}$ & & 1.98 & 1.46 & 0.02 & $* * *$ \\
\hline Total feed consumption, kg & & 93.7 & 97.5 & 1.19 & ns \\
\hline Feed conversion per $1 \mathrm{~kg}$ of BW gain, $\mathrm{kg} \mathrm{kg}^{-1}$ & & 2.46 & 2.58 & 0.03 & ns \\
\hline Weight of cold carcass, $\mathrm{kg}$ & 15.4 & 46.9 & 46.8 & 0.53 & ns \\
\hline Backfat thickness at the last rib, $\mathrm{mm}$ & 4.6 & 12.2 & 11.2 & 0.56 & ns \\
\hline Meatiness of basic cuts, $\%$ & 56.8 & 63.4 & 65.3 & 0.28 & $* *$ \\
\hline Spleen, g & 33 & 112 & 94 & 3.88 & $*$ \\
\hline Stomach, $\mathrm{g}$ & 216 & 472 & 411 & 11.28 & ns \\
\hline Liver, g & 556 & 1137 & 929 & 22.76 & $* * *$ \\
\hline Pancreas, g & 49 & 114 & 100 & 2.16 & $* *$ \\
\hline Heart, g & 103 & 280 & 277 & 4.70 & ns \\
\hline Kidney, g & 53 & 133 & 110 & 3.48 & $* *$ \\
\hline
\end{tabular}

Group: 0 - initial weight, A - semi ad libitum, $\mathrm{R}$ - restriction, ns not significant, ${ }^{*} P \leq 0.05,{ }^{*} P \leq 0.01,{ }^{* * *} P \leq 0.001$

Table 4

Production results in finishing period

Mast- und Schlachtergebnisse im 2. Mastabschnitt

\begin{tabular}{|c|c|c|c|c|c|c|c|}
\hline \multirow{2}{*}{ Item } & \multicolumn{4}{|c|}{ Group } & \multirow{2}{*}{ SEM } & \multicolumn{2}{|c|}{$P$} \\
\hline & $A C$ & $\mathrm{AO}$ & $\mathrm{RC}$ & RO & & G & 0 \\
\hline Initial body weight, $\mathrm{kg}$ & 60.4 & 60.4 & 61.3 & 61.0 & 0.42 & ns & ns \\
\hline Final body weight, $\mathrm{kg}$ & 103.4 & 104.9 & 103.3 & 104.9 & 0.40 & ns & ns \\
\hline Days of fattening & 52 & 47 & 48 & 47 & 0.61 & ns & * \\
\hline Daily weight gain, $\mathrm{g}$ & 834 & 934 & 876 & 946 & 9.03 & ns & $* * *$ \\
\hline Daily feed consumption, $\mathrm{kg}$ & 2.80 & 2.79 & 2.84 & 2.85 & 0.01 & $* * *$ & ns \\
\hline Total feed consumption, $\mathrm{kg}$ & 144.3 & 131.3 & 137.1 & 134.0 & 1.80 & ns & $*$ \\
\hline Feed conversion per $1 \mathrm{~kg}$ of BW gain, $\mathrm{kg} \mathrm{kg}^{-1}$ & 3.36 & 2.95 & 3.27 & 3.05 & 0.03 & ns & $* * *$ \\
\hline Weight of cold carcass, kg & 80.3 & 83.5 & 79.9 & 82.3 & 0.42 & ns & ** \\
\hline Backfat thickness at the last rib, $\mathrm{mm}$ & 15.8 & 15.4 & 15.7 & 15.3 & 0.54 & ns & ns \\
\hline Meatiness of basic cuts, $\%$ & 61.0 & 62.5 & 61.6 & 61.5 & 0.31 & ns & ns \\
\hline Spleen, $g$ & 145 & 157 & 148 & 164 & 4.39 & ns & ns \\
\hline Stomach, $\mathrm{g}$ & 560 & 557 & 552 & 563 & 6.27 & ns & ns \\
\hline Liver, g & 1443 & 1492 & 1431 & 1505 & 39.19 & ns & ns \\
\hline Pancreas, $\mathrm{g}$ & 146 & 161 & 151 & 174 & 3.05 & ns & $* *$ \\
\hline Heart, g & 370 & 394 & 382 & 397 & 5.77 & ns & $*$ \\
\hline Kidney, g & 160 & 171 & 159 & 170 & 4.17 & ns & ns \\
\hline
\end{tabular}

AC semi ad libitum in growing period and feed with $0 \%$ oil in finishing period, $\mathrm{AO}$ semi ad libitum in growing period and feed with $4 \%$ oil in finishing period, RC restrictive in growing period and feed with $0 \%$ oil in finishing period, RO restrictive in growing period and feed with $4 \%$ oil in finishing period, G level of feeding in growing period, 0 addition of linseed oil, ns not significant, ${ }^{*} P \leq 0.05,{ }^{* *} P \leq 0.01,{ }^{* * *} P \leq 0.001$

Compared to the carcasses of pigs from group $A$, those of pigs from group $\mathrm{R}$ were characterized by thinner backfat and greater meatiness $(P \leq 0.01)$ (Table 3$)$. Lower weights of spleen $(P \leq 0.05)$, stomach and liver $(P \leq 0.001)$, and pancreas and kidney $(P \leq 0.01)$ were 
found in animals from group R. In pigs weighing $104 \mathrm{~kg}$, no statistical differences were found between the groups in the meatiness of primal cuts (Table 4). Higher weights of pancreas $(P \leq 0.01)$ and heart $(P \leq 0.05)$ were found in animals receiving the linseed oil diet throughout the fattening period.

Table 5

Level of hormones and biochemical parameters in blood in growing period

Hormone und Blutindikatoren im 1. Mastabschnitt

\begin{tabular}{|c|c|c|c|c|c|}
\hline \multirow{2}{*}{ Item } & \multirow{2}{*}{ Group 0} & \multicolumn{2}{|c|}{ Group } & \multirow{2}{*}{ SEM } & \multirow{2}{*}{$P$} \\
\hline & & A & $\mathrm{R}$ & & \\
\hline$\overline{\mathrm{GH}}, \mu \mathrm{IU} \mathrm{\textrm {ml } ^ { - 1 }}$ & 1.11 & 0.61 & 0.89 & 0.06 & * \\
\hline $\mathrm{TSH}, \mu \mathrm{IU} \mathrm{ml^{-1 }}$ & 0.33 & 0.68 & 0.38 & 0.06 & * \\
\hline $\mathrm{T}_{3}, \mathrm{nmoll}^{-1}$ & 3.21 & 4.23 & 4.13 & 0.14 & ns \\
\hline $\mathrm{T}_{4}, \mathrm{nmol} \mathrm{I}^{-1}$ & 114.7 & 226.6 & 198.7 & 11.62 & ns \\
\hline Insulin, $\mu \mathrm{IU} \mathrm{\textrm {ml } ^ { - 1 }}$ & 22.4 & 18.7 & 17.8 & 1.52 & ns \\
\hline TP, $\mathrm{gl}^{-1}$ & 44.1 & 69.5 & 69.3 & 1.10 & ns \\
\hline$A L B, g^{-1}$ & 29.4 & 42.4 & 43.3 & 0.79 & ns \\
\hline $\mathrm{GLU}, \mathrm{mmol} \mathrm{l}^{-1}$ & 6.32 & 5.33 & 4.97 & 0.14 & ns \\
\hline BUN, mmol I-1 & 5.04 & 4.33 & 3.48 & 0.18 & * \\
\hline $\mathrm{TG}, \mathrm{mmol} \mathrm{I}^{-1}$ & 0.47 & 0.45 & 0.41 & 0.03 & ns \\
\hline $\mathrm{CH}, \mathrm{mmol} \mathrm{I}^{-1}$ & 2.87 & 2.66 & 2.43 & 0.06 & ns \\
\hline $\mathrm{HDL}-\mathrm{Ch}, \mathrm{mmol} \mathrm{I}^{-1}$ & 0.82 & 0.82 & 0.80 & 0.02 & ns \\
\hline 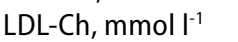 & 1.86 & 1.66 & 1.47 & 0.06 & ns \\
\hline VLDL-Ch, mmol I-1 & 0.19 & 0.19 & 0.17 & 0.01 & ns \\
\hline $\mathrm{CH} / \mathrm{HDL}-\mathrm{Ch}$ Index & 3.55 & 3.28 & 3.06 & 0.08 & ns \\
\hline
\end{tabular}

Group: 0 - initial weight, A - semi ad libitum, R - restriction, ns not significant, ${ }^{*} P \leq 0.05$

Table 6

Level of hormones and biochemical parameters in blood in finishing period

Hormone und Blutindikatoren im 2. Mastabschnitt

\begin{tabular}{|c|c|c|c|c|c|c|c|}
\hline \multirow{2}{*}{ Item } & \multicolumn{4}{|c|}{ Group } & \multirow{2}{*}{ SEM } & \multicolumn{2}{|c|}{$P$} \\
\hline & $A C$ & $\mathrm{AO}$ & $\mathrm{RC}$ & RO & & G & 0 \\
\hline 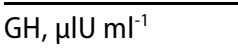 & 1.29 & 1.08 & 1.46 & 1.17 & 0.07 & ns & $\mathrm{ns}$ \\
\hline $\mathrm{TSH}, \mu \mathrm{IU} \mathrm{ml}{ }^{-1}$ & 0.65 & 0.63 & 0.58 & 0.65 & 0.05 & ns & ns \\
\hline $\mathrm{T}_{3}, \mathrm{nmol} \mathrm{I}^{-1}$ & 2.75 & 3.82 & 3.53 & 3.56 & 0.10 & ns & * \\
\hline $\mathrm{T}_{4}, \mathrm{nmol} \mathrm{I}^{-1}$ & 189.1 & 197.5 & 218.3 & 231.5 & 13.22 & ns & ns \\
\hline Insulin, $\mu \mathrm{IU} \mathrm{ml^{-1 }}$ & 16.5 & 22.2 & 15.2 & 23.3 & 1.46 & ns & * \\
\hline $\mathrm{TP}, \mathrm{gl}^{-1}$ & 72.0 & 73.6 & 71.4 & 72.5 & 0.80 & ns & ns \\
\hline ALB, $\mathrm{gl}^{-1}$ & 46.6 & 46.5 & 43.8 & 47.3 & 0.68 & ns & ns \\
\hline $\mathrm{GLU}, \mathrm{mmol} \mathrm{I}^{-1}$ & 4.26 & 4.37 & 4.52 & 4.61 & 0.17 & ns & ns \\
\hline BUN, $\mathrm{mmol} \mathrm{I}^{-1}$ & 4.60 & 4.11 & 3.70 & 3.79 & 0.16 & ns & ns \\
\hline $\mathrm{TG}, \mathrm{mmol} \mathrm{l}^{-1}$ & 0.48 & 0.42 & 0.42 & 0.42 & 0.02 & ns & ns \\
\hline $\mathrm{CH}, \mathrm{mmol} \mathrm{I}^{-1}$ & 2.68 & 2.51 & 2.62 & 2.40 & 0.05 & ns & ns \\
\hline $\mathrm{HDL}^{-C h}, \mathrm{mmol}^{-1}$ & 0.85 & 0.75 & 0.89 & 0.79 & 0.02 & ns & $* *$ \\
\hline $\mathrm{LDL}^{-C h}, \mathrm{mmoll}^{-1}$ & 1.67 & 1.58 & 1.50 & 1.45 & 0.04 & ns & ns \\
\hline VLDL-Ch, $\mathrm{mmol} \mathrm{I}^{-1}$ & 0.18 & 0.16 & 0.23 & 0.16 & 0.01 & ns & ns \\
\hline $\mathrm{CH} / \mathrm{HDL}-\mathrm{Ch}$ Index & 3.21 & 3.35 & 2.94 & 3.06 & 0.05 & $*$ & ns \\
\hline
\end{tabular}

AC semi ad libitum in growing period and feed with $0 \%$ oil in finishing period, AO semi ad libitum in growing period and feed with $4 \%$ oil in finishing period, RC restrictive in growing period and feed with $0 \%$ oil in finishing period, RO restrictive in growing period and feed with $4 \%$ oil in finishing period, G level of feeding in growing period, 0 addition of linseed oil, ns not significant, ${ }^{*} P \leq 0.05,{ }^{* *} P \leq 0.01$ 
At the end of the growing period, the blood serum of restrictively fed animals (group R) had a higher concentration of GH $(P \leq 0.05)$ and lower concentrations of TSH $(P \leq 0.05), \mathrm{T}_{3}$ and $T_{4}$ (Table 5) compared to intensively fed animals (group A). At the end of the finishing period, the blood serum of animals receiving linseed oil diets throughout fattening was characterized by a lower concentration of $\mathrm{GH}$ (no statistical differences) and higher concentrations of $\mathrm{T}_{3}(P \leq 0.05), \mathrm{T}_{4}$ (no statistical differences) and insulin ( $\left.P \leq 0.05\right)$ (Table 6). The level of feeding had no significant effect on the analysed hormones.

Compared to restrictively fed animals, intensively fed animals (group A) had higher serum levels of BUN $(P \leq 0.05), \mathrm{GLU}, \mathrm{TG}$, total $\mathrm{CH}$ and cholesterol fractions (Table 5). At the end of the finishing period, a significant effect of the linseed oil supplement on the level of HDL cholesterol was found in the blood serum of pigs weighing $104 \mathrm{~kg}(P \leq 0.01)$ (Table 6). The level of feeding had an effect on the ratio of total to HDL cholesterol $(P \leq 0.05)$.

In the fatty acid profile determined in the lipid fraction of $m$. semimembranosus in animals that were restrictively fed during the growing period (group R), the proportion of saturated fatty acid (SFA) and monosaturated fatty acid (MUFA) was lower and the proportion of $n-6$ PUFA $(P \leq 0.05)$ and n-3 PUFA (Table 7) was higher compared to those of intensively fed animals. In animals weighing $104 \mathrm{~kg}$, feeding level had a significant effect on some MUFA, n-6 PUFA and n-3 PUFA acids (Table 8). The linseed oil supplement did not have any significant effect on the proportions of C14:0, C18:0, C20:4 and C22:4 only.

Based on the fatty acid profile of backfat in animals weighing $61 \mathrm{~kg}$, a significant or highly significant effect of feeding level on the proportion of SFA (including C16:0), C16:1 and all of n-6 PUFA acids in the fatty acid profile was found (Table 9). In the fatty acid profile of backfat from animals weighing $104 \mathrm{~kg}$, the level of feeding had no significant effect on the proportions of analysed acids, whereas the linseed oil supplement had a significant effect on most of the acids analysed (Table 10).

Table 7

Profile of fatty acids in $m$. semimembranosus in growing period (\%)

Profil der Fettsäuren im M. semimembranosus im 1. Mastabschnitt (\%)

\begin{tabular}{|c|c|c|c|c|c|}
\hline \multirow{2}{*}{ Item } & \multirow{2}{*}{ Group 0} & \multicolumn{2}{|c|}{ Group } & \multirow{2}{*}{ SEM } & \multirow{2}{*}{$P$} \\
\hline & & $\mathrm{A}$ & $\mathrm{R}$ & & \\
\hline SFA & 38.40 & 38.00 & 37.45 & 0.33 & ns \\
\hline C 14:0 & 1.45 & 1.26 & 1.27 & 0.02 & ns \\
\hline C $16: 0$ & 25.77 & 23.37 & 23.09 & 0.19 & ns \\
\hline C 18:0 & 11.17 & 13.36 & 13.09 & 0.21 & ns \\
\hline MUFA & 46.85 & 43.99 & 43.45 & 0.34 & ns \\
\hline C $16: 1$ & 4.50 & 2.51 & 2.55 & 0.06 & ns \\
\hline C $18: 1$ & 42.35 & 41.47 & 40.91 & 0.33 & ns \\
\hline PUFA n-6 & 13.74 & 11.87 & 12.85 & 0.21 & $*$ \\
\hline C $18: 2$ & 11.63 & 10.44 & 11.28 & 0.19 & $*$ \\
\hline C $20: 4$ & 1.77 & 1.32 & 1.43 & 0.04 & ns \\
\hline C 22:4 & 0.35 & 0.12 & 0.14 & 0.01 & ns \\
\hline PUFA n-3 & 1.01 & 6.14 & 6.25 & 0.13 & ns \\
\hline C $18: 3$ & 0.57 & 5.47 & 5.44 & 0.13 & ns \\
\hline C 20:5 & 0.12 & 0.24 & 0.31 & 0.01 & $*$ \\
\hline C 22:5 & 0.20 & 0.34 & 0.41 & 0.01 & $* *$ \\
\hline C 22:6 & 0.11 & 0.09 & 0.09 & 0.01 & ns \\
\hline PUFA n-6/n-3 & 13.67 & 1.94 & 2.06 & 0.04 & ns \\
\hline PUFA/SFA & 0.39 & 0.47 & 0.51 & 0.01 & ns \\
\hline
\end{tabular}

Group: 0 - initial weight, A - semi ad libitum, $\mathrm{R}$ - restriction, ns not significant, ${ }^{*} P \leq 0.05,{ }^{*} P \leq 0.01$ 
Table 8

Profile of fatty acids in $m$. semimembranosus in finishing period (\%)

Profil der Fettsäuren im M. semimembranosus im 2. Mastabschnitt (\%)

\begin{tabular}{|c|c|c|c|c|c|c|c|}
\hline \multirow{2}{*}{ Item } & \multicolumn{4}{|c|}{ Group } & \multirow{2}{*}{ SEM } & \multicolumn{2}{|c|}{$P$} \\
\hline & $A C$ & $\mathrm{AO}$ & $\mathrm{RC}$ & RO & & $\mathrm{G}$ & 0 \\
\hline SFA & 38.49 & 38.70 & 39.71 & 36.70 & 0.30 & ns & * \\
\hline C 14:0 & 1.32 & 1.34 & 1.36 & 1.22 & 0.02 & ns & ns \\
\hline C 16:0 & 23.78 & 23.57 & 24.47 & 22.92 & 0.18 & ns & $*$ \\
\hline C 18:0 & 13.40 & 13.79 & 13.88 & 12.56 & 0.16 & ns & ns \\
\hline MUFA & 47.66 & 46.03 & 46.74 & 43.77 & 0.33 & * & $* *$ \\
\hline C $16: 1$ & 2.89 & 2.60 & 2.99 & 2.41 & 0.05 & ns & $* * *$ \\
\hline C $18: 1$ & 44.77 & 43.44 & 43.75 & 41.36 & 0.30 & * & $* *$ \\
\hline PUFA n-6 & 10.01 & 9.95 & 9.99 & 12.88 & 0.34 & * & $*$ \\
\hline C $18: 2$ & 8.76 & 8.72 & 8.72 & 11.61 & 0.30 & * & $*$ \\
\hline C $20: 4$ & 1.13 & 1.09 & 1.17 & 1.12 & 0.06 & ns & ns \\
\hline C 22:4 & 0.13 & 0.14 & 0.11 & 0.15 & 0.01 & ns & ns \\
\hline PUFA n-3 & 3.85 & 5.32 & 3.56 & 6.64 & 0.14 & ns & $* * *$ \\
\hline C $18: 3$ & 3.20 & 4.33 & 2.81 & 5.12 & 0.12 & ns & $* * *$ \\
\hline C 20:5 & 0.20 & 0.36 & 0.24 & 0.68 & 0.04 & * & $* * *$ \\
\hline C 22:5 & 0.35 & 0.50 & 0.41 & 0.71 & 0.03 & * & $* * *$ \\
\hline C 22:6 & 0.10 & 0.13 & 0.10 & 0.14 & 0.01 & ns & $* *$ \\
\hline PUFA n-6/n-3 & 2.65 & 1.88 & 2.80 & 1.93 & 0.04 & ns & $* * *$ \\
\hline PUFA/SFA & 0.36 & 0.40 & 0.34 & 0.54 & 0.02 & ns & $* * *$ \\
\hline
\end{tabular}

AC semi ad libitum in growing period and feed with $0 \%$ oil in finishing period, AO semi ad libitum in growing period and feed with $4 \%$ oil in finishing period, RC restrictive in growing period and feed with $0 \%$ oil in finishing period, RO restrictive in growing period and feed with $4 \%$ oil in finishing period, $G$ level of feeding in growing period, $O$ addition of linseed oil, ns not significant, ${ }^{*} P \leq 0.05,{ }^{* *} P \leq 0.01,{ }^{* * *} P \leq 0.001$

Table 9

Profile of fatty acids in back fat in growing period (\%)

Profil der Fettsäuren im Speck im 1. Mastabschnitt (\%)

\begin{tabular}{lrrrcc}
\hline Item & Group 0 & \multicolumn{2}{c}{ Group } & SEM & $P$ \\
\hline SFA & & $\mathrm{A}$ & $\mathrm{R}$ & & \\
C 14:0 & 36.13 & 36.68 & 34.99 & 0.30 & $*$ \\
C 16:0 & 1.51 & 1.15 & 1.12 & 0.03 & $\mathrm{~ns}$ \\
C 18:0 & 23.69 & 21.08 & 20.30 & 0.14 & $*$ \\
MUFA & 10.94 & 14.44 & 13.56 & 0.24 & $\mathrm{~ns}$ \\
C 16:1 & 47.58 & 42.61 & 41.56 & 0.36 & $\mathrm{~ns}$ \\
C 18:1 & 4.70 & 2.33 & 1.87 & 0.08 & $* *$ \\
PUFA n-6 & 42.87 & 40.28 & 39.69 & 0.35 & $\mathrm{~ns}$ \\
C 18:2 & 15.19 & 13.21 & 15.31 & 0.21 & $* * *$ \\
C 20:4 & 14.58 & 12.91 & 15.01 & 0.20 & $* * *$ \\
C 22:4 & 0.46 & 0.22 & 0.25 & 0.01 & $*$ \\
PUFA n-3 & 0.15 & 0.08 & 0.05 & 0.01 & $* *$ \\
C 18:3 & 1.09 & 7.51 & 8.14 & 0.18 & $\mathrm{~ns}$ \\
C 20:5 & 0.88 & 7.09 & 7.71 & 0.17 & $\mathrm{~ns}$ \\
C 22:5 & 0.07 & 0.12 & 0.10 & 0.01 & $\mathrm{~ns}$ \\
C 22:6 & 0.09 & 0.22 & 0.27 & 0.01 & $\mathrm{~ns}$ \\
PUFA n-6/n-3 & 0.07 & 0.07 & 0.07 & 0.01 & $\mathrm{~ns}$ \\
PUFA/SFA & 13.96 & 1.76 & 1.89 & 0.03 & $*$ \\
\hline
\end{tabular}

Group: 0 - initial weight, $A$ - semi ad libitum, $\mathrm{R}$ - restriction, ns not significant, $\quad{ }^{*} P \leq 0.05,{ }^{* *} P \leq 0.01,{ }^{* * *} P \leq 0.001$ 
Table 10

Profile of fatty acids in back fat in finishing period (\%)

Profil der Fettsäuren im Speck im 2. Mastabschnitt (\%)

\begin{tabular}{|c|c|c|c|c|c|c|c|}
\hline \multirow{2}{*}{ Item } & \multicolumn{4}{|c|}{ Group } & \multirow{2}{*}{ SEM } & \multicolumn{2}{|c|}{$P$} \\
\hline & $\mathrm{AC}$ & $\mathrm{AO}$ & $\mathrm{RC}$ & RO & & G & 0 \\
\hline SFA & 40.78 & 38.94 & 39.68 & 39.68 & 0.24 & ns & ns \\
\hline C 14:0 & 1.25 & 1.17 & 1.21 & 1.19 & 0.01 & ns & $*$ \\
\hline C 16:0 & 23.03 & 21.46 & 22.24 & 21.78 & 0.19 & ns & * \\
\hline C 18:0 & 16.51 & 16.32 & 16.23 & 16.72 & 0.12 & ns & ns \\
\hline MUFA & 44.32 & 42.12 & 44.40 & 41.39 & 0.19 & ns & $* * *$ \\
\hline C 16:1 & 2.22 & 1.79 & 2.15 & 1.70 & 0.03 & ns & $* * *$ \\
\hline C $18: 1$ & 42.10 & 40.33 & 42.25 & 39.68 & 0.20 & ns & $* * *$ \\
\hline PUFA n-6 & 10.64 & 11.46 & 11.41 & 11.49 & 0.16 & ns & ns \\
\hline C $18: 2$ & 10.40 & 11.26 & 11.16 & 11.28 & 0.16 & ns & ns \\
\hline C 20:4 & 0.16 & 0.13 & 0.17 & 0.14 & 0.01 & ns & $* * *$ \\
\hline C $22: 4$ & 0.08 & 0.07 & 0.08 & 0.08 & 0.01 & ns & ns \\
\hline PUFA n-3 & 4.26 & 7.47 & 4.52 & 7.44 & 0.10 & ns & $* * *$ \\
\hline C $18: 3$ & 3.91 & 7.01 & 4.14 & 6.96 & 0.09 & ns & $* * *$ \\
\hline C 20:5 & 0.08 & 0.11 & 0.09 & 0.10 & 0.01 & ns & ns \\
\hline C $22: 5$ & 0.20 & 0.28 & 0.21 & 0.30 & 0.01 & ns & $* * *$ \\
\hline C 22:6 & 0.07 & 0.08 & 0.07 & 0.08 & 0.01 & ns & ns \\
\hline PUFA n-6/n-3 & 2.51 & 1.53 & 2.55 & 1.54 & 0.02 & ns & $* * *$ \\
\hline PUFA/SFA & 0.37 & 0.49 & 0.40 & 0.48 & 0.01 & ns & $* * *$ \\
\hline
\end{tabular}

AC semi ad libitum in growing period and feed with $0 \%$ oil in finishing period, AO semi ad libitum in growing period and feed with $4 \%$ oil in finishing period, RC restrictive in growing period and feed with $0 \%$ oil in finishing period, RO restrictive in growing period and feed with $4 \%$ oil in finishing period, $G$ level of feeding in growing period, 0 addition of linseed oil, ns not significant, ${ }^{*} P \leq 0.05,{ }^{* *} P \leq 0.001$

\section{Discussion}

The approx. $26 \%$ decrease in feeding level during the growing period reduced the rate of growth by approx. 30\%. These findings confirm the relationships reported by other authors (BEE et al. 2007, GONDRET and LEBRET 2007, HEYER and LEBRET 2007), who observed a linear relationship between feed intake and growth rate.

In the present study, compared to pigs fed semi-ad libitum, animals that were restrictively fed during the growing period consumed more feed during the finishing period regardless of the type of feed. Higher feed intake was associated with higher daily gains (DAZA et al. 2006, HEYER and LEBRET 2007), although the relationships were not always linear. In a study by GONDRET and LEBRET (2007), 14\% higher daily feed intake increased the growth rate by just $7 \%$. Higher gains sometimes result from better feed conversion rather than higher feed intake (OKSBJERG et al. 2002).

In the present experiment, the compensatory growth of pigs subjected to restricted feeding during the growing period was not complete. It should be stated, however, that this growth was more noticeable in animals that received the diet containing no linseed oil during the finishing period. A similar reaction of animals was observed by other authors. In a study by HEYER and LEBRET (2007), a 35\% lower feeding level during fattening from 30 to $70 \mathrm{~kg}$ b.w. proved too high for complete compensatory growth to occur. Although finishing animals had $13 \%$ higher weight gains than animals fed ad libitum throughout, they reached a body weight of $110 \mathrm{~kg} 19$ days later. Even enriching 
the feeds with rapeseed oil during the post-restriction period (80-105 kg b.w.) (MASON et al. 2005) did not permit the pigs to achieve the same rate of growth as animals fed ad libitum diets without oil during the whole fattening period (35-105 kg).

Compensatory growth in pigs occurs when feed restriction is not too high and not too long (SKIBA 2005). It is most often observed over short periods that last several days to approx. 3 weeks after termination of feed restriction (SKIBA et al. 2001). This growth does not always concern the whole body, and the response of tissues and organs depends on their metabolic activity. During the period of underfeeding, the most active organs (such as liver and kidneys) show the greatest weight loss. When the feed supply is high, these tissues show compensatory growth (SKIBA et al. 2001, WIĘCEK et al. 2006, HEYER and LEBRET 2007). These relationships were also observed in the present experiment. The loss of organ weight by more than $10 \%$, caused by restrictive feeding, was fully compensated when animals were fed semi-ad libitum.

The restrictive feeding strategy used in the growing period increased the meatiness of pigs as in the studies by NONN and JEROCH (2000), KUSEC et al. (2005), BEE et al. (2006a, 2006b, 2007), DAZA et al. (2006) and HEYER and LEBRET (2007). The high concentration of the growth hormone $(\mathrm{GH})$ observed in animals during the period of limited feed supply increases the mobilization of fatty acids from adipose tissue and the use of these acids as a source of energy (HORNICK et al. 2000). Pigs fed less intensively are known to deposit less fat (OKSBJERG et al. 2002, MASON et al. 2005). NIELSEN et al. (1995) showed that the blood level of GH was higher in pigs selected for reduced backfat thickness compared to unselected pigs.

When realimentation ended, the fatness of pigs that were restrictively fed during the growing period was not higher than in pigs fed semi-ad libitum throughout, although BLUM et al. (1985) hold that the increased secretion of insulin observed during the initial stage of realimentation may serve as a signal to initiate anabolic processes. This may lead to greater deposition of fat, but this phenomenon is not always observed for all muscle groups (GONDRET and LEBRET 2007).

The period of limited feed supply is paralleled by a low level of thyroid hormones (SAWOSZ et al. 2005) and increased production and secretion of the growth hormone. Lower concentrations of $T_{3}$ and $T_{4}$ permit the body to save energy by reducing basal metabolic rate (HORNICK et al. 2000).

The indicators of protein and lipid metabolism depend on the level of feeding and nutrient concentration in feed. In the blood serum of restrictively fed animals, a slight decrease in these indicators was found. Similar relationships were observed by SAWOSZ et al. (2005) in pigs fed restrictively over a 100-day period, where a decrease in metabolizable energy from 13.5 to $9.5 \mathrm{MJ}$ and in protein from 17.7 to $12.6 \%$ per $\mathrm{kg}$ feed reduced the concentration of hormones significantly but lowered TG, GLU and CH levels to a small degree. In the present study, the continued administration of linseed oil diets during the finishing period (groups $\mathrm{AO}$ and $\mathrm{RO}$ ) caused a slight reduction in the level of total cholesterol and its fractions.

Restricted feeding may alter the relationships between the intake of fatty acids and the content of individual acids in adipose tissue. The low deposition of fat, which takes place in restrictively fed animals, is paralleled by lower de novo synthesis of saturated and 
monounsaturated fatty acids. This determines a higher proportion of unsaturated acids in the total acid profile (BIEDERMANN et al. 2000). When fat deposition is low, PUFA percentage increases but the synthesis does not follow the same pattern in all tissues (DUNKER et al. 2007, WIĘCEK et al. 2008).

It is concluded from the present experiment that despite the small differences between the groups, restricted feeding during the growing period had a dietetically positive effect (more n-3 PUFA) on the fatty acid profile of backfat and the lipid fraction of $m$. semimembranosus in pigs after the end of the finishing period. In the fatty acid profile of the lipid fraction of $m$. longissimus dorsi and $m$. semimembranosus, WIĘCEK and SKOMIAŁ (2004) reported lower proportions of SFA and MUFA and a higher proportion of $\mathrm{n}-6$ and $\mathrm{n}-3$ PUFA in pigs fed restrictively during the growing period and semi-ad libitum during the finishing period, compared to animals fed semi-ad libitum throughout fattening. DUNKER et al. (2007) did not confirm a beneficial effect (i.e. greater proportion of n-3 PUFA) of the restriction-compensation feeding strategy on the fatty acid profile of $m$. longissimus dorsi, backfat and liver.

The profile of fatty acids is influenced more by the type of feed given than by the level of feeding (WIĘCEK and SKOMIAŁ 2004, VÁCLAVKOVÁ and BEČKOVÁ 2007, WIĘCEK et al. 2008). The PUFA content of animal muscles and fat is strictly correlated with the PUFA content of feed (RILEY et al. 2000, FLIS et al. 2007). Even when linseed was fed for a brief period of 7 days ( $150 \mathrm{~g} / \mathrm{kg}$ feed), it changed the profile of fatty acids in pork (ROMANS et al. 1995). In the present study, the $4 \%$ oil supplement to the feed reduced the $n-6$ to $n-3$ PUFA ratio, which is dietetically desirable (WOOD et al. 2003) but may negatively impact the taste value of meat ( $Ł Y C Z Y N ́ S K I$ et al. 2003). At the end of the finishing period, despite the lower proportion of $n-3$ PUFA in the total acid profile, the $n-6$ to $n-3$ PUFA ratio was still less than 4 in pigs that received feeds without oil during this period.

In conclusion, the level of feeding and the type of feed had an effect on the growth rate, meatiness, weight of internal organs, concentration of hormones and indicators of protein and lipid metabolism, and fatty acid profile of $m$. semimembranosus and backfat in pigs.

\section{References}

Bee G, Biolley C, Dougoud B, Guex G, Herzog W (2007) Growth performance, carcass characteristics, and meat quality traits as affected by the birth weight and the applied feeding strategies during the growing and finishing period in pigs. Arch Tierz 50 Special Issue, 70-1

Bee G, Calderini M, Biolley C, Guex G, Herzog W (2006a) Changes of the histochemical properties and meat quality traits of porcine muscles during growth. I. Effect of feed restriction in pigs slaughtered at the same age and varying body weight. Arch Tierz 49 Special Issue, 20-4

Bee G, Calderini M, Biolley C, Guex G, Herzog W (2006b) Changes of the histochemical properties and meat quality traits of porcine muscles during growth. II. Effect of feed restriction in pigs slaughtered at the same body weight and varying age. Arch Tierz 49 Special Issue, 62-6

Biedermann G, Jatsch C, Peschke W, Lindner JP, Wittmann W (2000) Fattening and carcass performance and meat- and fat quality of Piétrain pigs of different MHS-genotype and sex. II. Fatty acid pattern of the adipose tissues back fat, leaf fat and intermuscular fat and of the total- and phospholipids of the M. long dorsi. Arch Tierz 43, 165-78 [in German]

Blum JW, Schnyder W, Kunz PL, Blom AK, Bickel H, Schürch A (1985) Reduced and compensatory growth: endocrine and metabolic changes during food restriction and refeeding in steers. J Nutr 115, 417-24

Daza A, Olivares A, López-Bote C (2006) Effect of a moderate feed restriction on subsequent growth and body composition in pigs raised under high environmental temperatures. J Anim Feed Sci 15, 417-26 
Daza A, Rey Al, Menoyo D, Bautista JM, Olivares A, López-Bote CJ (2007) Effect of level of feed restriction during growth and/or fattening on fatty acid composition and lipogenic enzyme activity in heavy pigs. Anim Feed Sci Tech 138, 61-74

Dunker A, Rey Al, López-Bote CJ, Daza A (2007) Effect of the feeding level during the fattening phase on the productive parameters, carcass characteristics and quality of fat in heavy pigs. J Anim Feed Sci $16,621-35$

Flis M, Sobotka W, Antoszkiewicz Z, Lipiński K, Zduńczyk Z (2007) Effect of husked and naked oat used in the diets supplemented with linseed oil on the growth performance of pigs, carcass and meat quality. Arch Tierz 50 Special Issue, 161-71

Gondret F, Lebret B (2007) Does feed restriction and re-alimentation differently affect lipid content and metabolism according to muscle type in pigs (Sus scrofa)? Comp Bioch Physiol Part A, 147, 375-82

Heyer A, Lebret B (2007) Compensatory growth response in pigs: Effects on growth performance, composition of weight gain at carcass and muscle levels, and meat quality. J Anim Sci 85, 769-78

Hornick JL, Van Eenaeme C, Gérard O, Dufrasne I, Istasse L (2000) Mechanisms of reduced and compensatory growth. Domest Anim Endocrinol 19, 121-32

Kusec G, Baulain U, Henning M, Köhler $P$, Kallweit E (2005) Fattening, carcass and meat quality traits of hybrid pigs as influenced by MHS genotype and feeding systems. Arch Tierz 48, 40-9

Leibetseder J (1996) Influence on the composition of animal fat by nutrition. Arch Tierz 39, 333-45 [in German]

Łyczyński A, Pospiech E, Urbaniak N (2003) Nutritional factors modifying pork quality. Anim Sci Pap Rep 21, 93-107

Mason LM, Hogan SA, Lynch A, O'Sullivan K, Lawlor PG, Kerry JP (2005) Effects of restricted feeding and antioxidant supplementation on pig performance and quality characteristics of longissimus dorsi muscle from Landrace and Duroc pigs. Meat Sci 70, 307-17

Nielsen VH, Larsen NJ, Agergaard N (1995) Association of DNA polymorphism in the growth-hormone gene with basal plasma growth hormone concentration and production traits in pigs. J Anim Breed Gen 112, 205-12

Nonn $\mathrm{H}$, Jeroch $\mathrm{H}(2000)$ Investigation on N-reduced feeding and use of free amino acids in fattening pigs. Arch Tierz 43, 179-91 [in German]

Oksbjerg N, Sørensen MT, Vestergaard M (2002) Compensatory growth and its effect on muscularity and technological meat quality in growing pigs. Acta Agric Scand, Sect A, Animal Sci 52, 85-90

Peinado B, Almela L, Duchi N, Poto A (2009) Effect of two different diets on carcass and meat quality traits of Chato Murciano pigs. Arch Tierz 52, 150-60

PN - ISO 5508 (1996) Animal and vegetable fats and oils-Analysis by gas chromatography of methyl esters of fats acids [in Polish]

PN - ISO 5509 (1996) Animal and vegetable fats and oils-Preparation of methyl esters of fatty acids [in Polish]

Riley PA, Enser M, Nute GR, Wood JD (2000) Effects of dietary linseed on nutritional value and other quality aspects of pig muscle and adipose tissue. Anim Sci 71, 483-500

Romans JR, Wulf DM, Johnson RC, Libal GW, Costello WJ (1995) Effects of ground flaxseed in swine diets on pig performance and on physical and sensory characteristics and omega-3 fatty acid content of pork: Il. Duration of 15\% dietary flaxseed. J Anim Sci 73, 1987-99

Różycki M (1996) Procedures of pig evaluation at pig performance testing stations. State of breeding and evaluation results of swine. IZ Balice XIV, 69-82 [in Polish]

Saggau E, Beyer M, Klein M, Schadereit R, Derno M, Jentsch W, Scholze H (2000) Effects of dietary protein quality on energy metabolism and thyroid hormone status in growing pigs. Arch Tierz 43, 633-47

Sawosz E, Chwalibog A, Skomiał J, Kosieradzka I, Zięcik AJ (2005) The effect of dietary energy concentration on the hormone profile and lipid metabolism in growing pigs. J Anim Feed Sci 14, Suppl 1, 393-96

Skiba G (2005) Physiological aspects of compensatory growth in pigs. J Anim Feed Sci 14, Suppl 1, $191-203$

Skiba G, Fandrajewski H, Raj S, Weremko D (2001) The performance and body composition of growing pigs during protein or energy deficiency and subsequent realimentation. J Anim Feed Sci 10, 633-47

SPSS 12.0 for Windows user's guide (2006) by SPSS Ins. USA

Václavková E, Bečková R (2007) Effect of linseed in pig diet on meat quality and fatty acid content. Arch Tierz 50 Special Issue, 144-51

Więcek J, Rekiel A, Skomiał J (2006) Weight of internal organs of pigs fed restrictively during the growing period and given linseed oil diets during the finishing period. Ann Anim Sci Suppl 2/1, 225-29 
Więcek J, Rekiel A, Skomiał J (2008) Fatty acids profile of back and kidney fat in compensatory fattening of pigs. Rocz Nauk PTZ 4, 1, 137-44 [in Polish]

Więcek J, Skomiał J (2004) Restricted feeding and linseed oil as modifiers of the fatty acid profile in pork. J Anim Feed Sci 13 Suppl 2, 43-6

Wood JD, Richardson RI, Nute GR, Fisher AV, Campo MM, Kasapidou E, Sheard PR, Enser M (2003) Effects of fatty acids on meat quality: a review. Meat Sci 66, 21-32

Received 27 August 2008, accepted 26 November 2009.

Corresponding author:

JUSTYNA WIĘCEK

email: justyna_wiecek@sggw.pl

Department of Pig Breeding, Faculty of Animal Sciences, Warsaw University of Life Sciences, Ciszewskiego 8, 02-786 Warszawa, Poland 